\title{
REPRODUCTIVE BIOLOGY OF VISCUM CRUCIATUM (VISCACEAE) IN SOUTHERN SPAIN
}

\author{
ABELARDO APARICIO, ${ }^{1, *}$ MARIA JESUS GALLEGO, ${ }^{*}$ AND CARLOS VÁZQUEZ $\dagger$ \\ *Departamento de Biología Vegetal y Ecología, Facultad de Farmacia, Universidad de Sevilla, 41012 Sevilla, Spain; and \\ †Aula de la Naturaleza, Avenida de la Diputación s/n, 11670 El Bosque, Cádiz, Spain
}

\begin{abstract}
The reproductive biology of the dioecious Viscum cruciatum, one of the few viscaceous mistletoes occurring in Europe, was investigated. The male flower is $7.2 \mathrm{~mm}$ long and lemon-scented, produces ca. 58,000 pollen grains, and has a dry mass of $14 \mathrm{mg}$, and thus a low relative staminate effort (RSE) value of 4,059 . Female flowers, ca. $3 \mathrm{~mm}$ long, $2.7 \mathrm{mg}$ dry mass, secrete small amounts of nectar $(0.05 \mathrm{mg}$ sugar/d). A stigma is not apparent. Flowers inside nylon bags (i.e., insect-free) set significantly less fruit than control branches open to natural pollination. Pollination is performed by insects. Flowers bagged against insects but not wind set some fruit. Flowers bagged with dense cloth excluding wind and insect pollination did not set any fruit. Agamospermous embryo production does not take place in this species and cannot be the cause of the shift in sex-ratio toward females. Fruits can contain one (45\%), two (43.6\%), three $(11 \%)$, or four $(0.3 \%)$ embryos, which may not be true polyembryony but may result from the partial or complete fusion of the chlorophyllous endosperm. Fruit size is not correlated with the number of embryos per "seed" but probably with other ecological or maternal factors. Although a dormancy period was not observed, flowering and fruiting are restricted mainly to winter. Nevertheless, the pattern of flowering differed significantly between the two years studied, being longer and less overlapping during 1991 (only in the females). The fruit set was also lower in 1991.
\end{abstract}

\section{Introduction}

The Viscaceae, formally separated from the Loranthaceae (Barlow 1964), is a group of hemiparasitic shrublets of pantropical distribution with a few species extending into temperate areas in both hemispheres. It is composed of seven genera and about $400 \mathrm{spp}$., many of which cause damage in wild and cultivated plants. The family has been studied from many different points of view since the late nineteenth century (Gill and Hawksworth 1961).

These plants are highly specialized in their hemiparasitic habit, showing a wide range of unusual features in their embryology (Bhatnagar and Johri 1983). Conventional ovules are not found and, as an example of extreme reduction, in Viscum the archesporium develops hypodermally at the base of the ovary. Each archesporial cell may undergo meiosis to produce an Allium-type embryo sac (Bhandari and Vohra 1983). Although most Viscaceae develop a unique embryo sac, probably several of them may be produced in each ovary at least in V. cruciatum (A. Aparicio, personal observation) and $V$. album. The fruit, which has been defined as a pseudoberry enclosing a single "naked seed" (Bhandari and Vohra 1983), can often contain several embryos within the chlorophyllous endosperm. Salle (1983) indicated that the "seed" of $V$. album possessed one, two, or three embryos. The fruits in the family are normally fresh and largely bird-dispersed (Godschalk 1983a, 1983b, 1985). Nevertheless, some members, such as Arceutobium or Kor-

${ }^{1}$ Author for correspondence and reprints.

Manuscript received May 1994; revised manuscript received August 1994. thansella, have developed explosive fruits (Barlow 1983).

The reproductive biology of most of the genera of the Viscaceae is unknown, apart from the extensive work on the biology and management of the dwarf mistletoes (Arceutobium) in North America (Hawksworth 1961; Hawksworth and Wiens 1972; Hawksworth and Johnson 1989). Barlow (1983, p. 33), stated that "the pollination mechanisms in the family have not been critically studied," but insect pollination is generally assumed. Hatton (1966) found greater efficiency for wind than for insect pollination in $V$. album. There is no literature on floral biology and fruit set ratios under natural and/or controlled pollination in the Viscaceae. Life cycles and phenology have been investigated by Fyfe (1969) and Fronchot and Sallé (1980) for $V$. album from Europe and by Godschalk $(1983 c)$ for $V$. combreticola, Tapinathus natalitius, and T. leendertziae from South Africa. These two Viscum species differ significantly in their phenological patterns.

The genus Viscum has ca. 100 spp. mostly confined to tropical Africa and Madagascar and to a lesser extent to southern Asia (Barlow 1983). In Europe $V$. album and $V$. cruciatum together with Arceutobium oxycedri are the only viscaceous mistletoes. Viscum album is a polymorphic species parasitizing many woody species (Malus, Populus, Quercus, Pinus, Abies) throughout Europe and Asia (Danser 1941). Viscum cruciatum, a less polymorphic species, is localized in some Mediterranean areas (southern Spain, northern Morocco) and in the Middle East and centralsouthern Asia. Characterized by its dichotomous branching, basal decussate leaves and bright red berries, it parasitizes mainly Olea europaea and to a lesser extent Prunus dulcis, Crataegus mon- 
ogyna, Retama sphaerocarpa, Spartium junceum, Phyllirea latifolia, Rhamnus alaternus, $R$. lycioides, and Hedera helix (Aparicio 1993). Nevertheless, these two mistletoes have been claimed to be the same species (Meyer von Freyhold 1987).

For this genus, information has been collected in recent years on histology and host resistance mechanisms (Fronchot et al. 1978; Sallé 1979a, $1979 b$; Hariri et al. 1990), chromosome numbers and biogeography, as well as chromosomal rearrangements in relation to origin and control of dioecy (Wiens and Barlow 1973, 1975, 1979; Barlow and Wiens 1975, 1976; Mechelke 1976; Barlow et al. 1978; Barlow 1981, 1983; Aparicio 1991, 1993), and phytochemistry (Ayuso et al. 1985, 1987).

We have investigated the reproductive biology of the largely unknown Mediterranean mistletoe $V$. cruciatum with special emphasis on floral and fruit characteristics, fruit set under controlled pollination conditions, annual cycle, and phenology.

\section{Material and methods}

\section{STUDY SITE}

The study was conducted during 1989-1992 in three populations (A, B, and C) within the Parque Natural de la Sierra de Grazalema, Cádiz province, south Spain. The area has a markedly Mediterranean climate with a mean annual temperature of ca. $15^{\circ} \mathrm{C}$ and mean annual rainfall exceeding in some stations $2,000 \mathrm{~mm} \mathrm{~m}^{-2}$; a detailed description of abiotic and floristic features of the area is presented by Aparicio and Silvestre (1987).

Population $\mathrm{A}$ is in an open vegetation near the town of Zahara (Cerro de la Breña, UTM 30S TF8378, $660 \mathrm{~m}$ a.s.l.). Mistletoes are growing on old, abandoned olive trees. Pistacia terebinthus, $P$. lentiscus, Ceratonia siliqua, and Phyllirea latifolia are the main accompanying woody species in this area. Population B grows on Crataegus monogyna in the understory of a dense mixed forest of Abies pinsapo and Quercus faginea near Grazalema (Llanos del Revés, UTM 30S TF8573, $740 \mathrm{~m}$ a.s.1.). Lonicera implexa and Rubus ulmifolius are the main accompanying species. Population $\mathrm{C}$ also grows on Crataegus monogyna, accompanied by Prunus spinosa, Berberis australis, and Ulex parviflorus near Grazalema (below the Cerro de San Cristóbal, UTM 30S TF8671, 1,260 $\mathrm{m}$ a.s.l.). The populations are 2$8 \mathrm{~km}$ from each other.

\section{FLORAL AND FRUIT CHARACTERISTICS}

We air-dried and weighed 234 male and 789 female flowers from nine and seven randomly chosen individual plants, respectively, and also measured 200 flowers from 10 male plants and
789 from seven females. We estimated the mean number of pollen grains per flower by macerating two flowers of 14 randomly chosen individual plants in $1 \mathrm{~mL}$ of $2 \%$ aqueous Triton containing a few drops of safranine. We sampled 10 aliquots of $5 \mu \mathrm{L}$ each to count all pollen grains under a microscope $(\times 400)$. On this basis, the relative staminate effort (RSE; Herrera 1987), or pollen yield per milligram of flower dry mass, was calculated. This variable correlates with the pollination mechanism; it is high in anemophilous plants and low in enthomophilous ones.

Although male flowers never secrete nectar (A. Aparicio, personal observation), female flowers produce some. The daily nectar production in flowers enclosed in plastic bags at room temperature (Herrera 1985) is negligible. In this study, however, weekly observations in the field revealed small amounts of viscous (40\%-90\%) nectar. For this reason, the volume and concentration of nectar were determined in a pooled sample of 134 flowers from five female plants during 1990 in population A, which had been in plastic bags for $1 \mathrm{wk}$ under laboratory conditions. Nectar was collected with $10-\mu \mathrm{L}$ micropipettes and the concentration read with Bellingham \& Standley refractometers.

Floral scent of male flowers is perceptible in the field, but we noticed it stronger inside the plastic bags used for nectar collection. Female flowers became scentless even after 1 wk inside the bags.

In population A, 100 fruits from eight randomly chosen plants were weighed and the number of embryos noted. The number of embryos was recorded from 353 fruits. The equatorial diameter of 124 randomly chosen fruits from three individuals from population $\mathrm{A}$ and 106 fruits from five individuals from population $\mathrm{C}$ was recorded.

The gross morphology of the "seeds" was studied by transverse hand sections mounted in lactic acid for $3 \mathrm{~d}$, observed, and photographed under a light microscope.

\section{POllinAtion AND FRUIT SET}

To determine the extent of wind and insect pollination in this species as well as to test for agamic embryo production (Dobrescu and Ghenciu 1974, as cited in Barlow et al. 1978; Aparicio 1993), we tagged three branches of 20 female plants in population A (A90) in December 1989: (i) bagged with dense cloth (excluding wind and insect pollination), (ii) bagged with $0.5-\mathrm{mm}$ nylon cloth (excluding insects), and (iii) a control branch under natural pollination conditions. We counted the number of flower buds in each. In January 1991 we tagged branches again, but only branch types ii and iii (nylon and control) in population A (A91) and the three kinds of branches in B (B91). Since many tagged plants were broken by 
Table 1

NuMBER OF FLOWERS AND INDIVIDUAL PLANTS (in parentheses) BEFORE AND AFTER LOSSES IN EACH OF THE THREE TAGGED BRANCHES AND POPULATIONS

\begin{tabular}{|c|c|c|c|c|c|c|}
\hline & \multicolumn{2}{|c|}{ Cloth } & \multicolumn{2}{|c|}{ Nylon } & \multicolumn{2}{|c|}{ Control } \\
\hline & Initial & Final & Initial & Final & Initial & Final \\
\hline A90 & $1,110(20)$ & $405 \quad(8)$ & $875(20)$ & 409 (9) & $1,065(20)$ & $678(13)$ \\
\hline A91 & $\ldots$ & & 568 (11) & $529 \quad(8)$ & $501(11)$ & 443 (9) \\
\hline B91 $\ldots$ & 224 & 224 & $735(12)$ & $735(12)$ & 460 (10) & 460 (10) \\
\hline Total & $1,334(23)$ & 629 (11) & $2,178(43)$ & $1,673(29)$ & $2,026(41)$ & $1,581(32)$ \\
\hline
\end{tabular}

wind, dried during the summer, or eaten by animals, the initial number of experimental plants and flowers was significantly lowered (table 1). Bags were removed 2-3 mo later when the flowering season finished.

\section{Phenology AND FRUIT REMOVAL}

Flowers on the control and tagged branches in both populations during 1990 (A90) and 1991 (A91, B91) in male and female plants were recorded weekly. We calculated the overlap index, $Z=c / n$ (Primack 1980; J. Herrera 1986), at sex level (males and females separately) and for the whole population. Because of the large number of flowers per individual and the difficulty of observing branches $2-3 \mathrm{~m}$ above the ground, we could not observe the entire plant and restricted our observations to branches within reach. We assume that the flowering dynamics of the tagged branches is consistent with that of the whole plant. For each possible pair of tagged individual plants, $c$ was calculated as the ratio of the number of flowers on the census dates on which both plants showed "intense flowering" ( $>50 \%$ of anthesis; Primack 1980) to the total number on the census dates of intense flowering for that pair. The degree of overlap $(Z)$ is the mean value obtained from all the possible pairs $(n)$ and would be 1 with absolute overlap and 0 without overlap. Synchrony was computed as the maximum number of plants found during the flowering period of the population with intense flowering at the same time.
In addition, we recorded the presence or absence of developing ovaries, young and ripe fruits, vegetative growth, and flower buds weekly in all plants. During 1991, a removal sequence of fruits was followed. For this purpose, 150 fruits of five individuals in population $A$ and 117 fruits of four individuals in population $\mathrm{B}$ were tagged. The remaining fruits were counted weekly.

\section{Results}

\section{PHENOLOGY AND FRUIT REMOVAL}

The vegetative growth resumes in December or January, when the plants are about to flower (fig. 1). This results in the formation of many lateral, mostly verticillate, new branches that will produce a portion of the flower buds for the next year. These usually appear in early summer by the end of the flowering period and slowly develop until the next winter when they bloom. Microsporogenesis and megasporogenesis take place in autumn, a little earlier in the males than in females. The flowering phenology patterns were different between the years, but the overall duration of flowering at the population level is the mean duration of the flowering span of females $(r=0.98, P<.1)$. In A90 there was a rather short and intense flowering period with an overall duration of 8 wk (table 2; fig. 2) starting in late January with high overlap and synchrony, so most of the individuals flowered in the same weeks and showed intense flowering. In 1991, the flowering started 1 wk later than in 1990 in both popula-

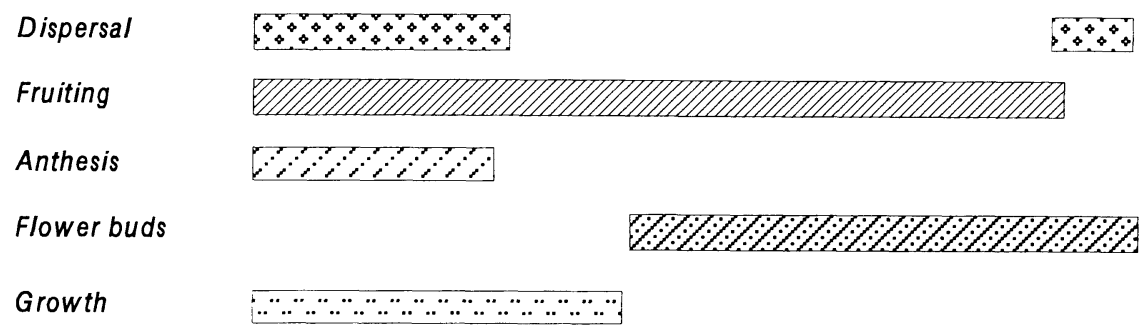

\begin{tabular}{llllllllllll}
\hline$J$ & $F$ & $M$ & $A$ & $M$ & $J$ & $J$ & $A$ & $S$ & $O$ & $N$ & $D$
\end{tabular}

Fig. 1 Timing and duration of phenophases in Viscum cruciatum during the period of study 
Table 2

OVERLAP INDEX, OVERALL DURATION OF BLOOMING PERIOD, AND SYNCHRONY AT SEX AND POPULATION LEVEL

\begin{tabular}{|c|c|c|c|c|}
\hline & Overlap & $\begin{array}{l}\text { Overall } \\
\text { no. of } \\
\text { census } \\
\text { dates }\end{array}$ & $\begin{array}{l}\text { Syn- } \\
\text { chrony }\end{array}$ & $N$ \\
\hline \multicolumn{5}{|l|}{ A90: } \\
\hline Males ........ & $.57 \pm .022$ & 8 & 13 & 14 \\
\hline Females.... & $.66 \pm .014$ & 7 & 20 & 20 \\
\hline Population .. & $.58 \pm .013$ & 8 & & \\
\hline \multicolumn{5}{|l|}{ A91: } \\
\hline Males....... & $.60 \pm .048$ & 13 & 8 & 9 \\
\hline Females..... & $.21 \pm .030$ & 14 & 6 & 12 \\
\hline Population .. & $.34 \pm .030$ & 14 & & \\
\hline \multicolumn{5}{|l|}{ B91: } \\
\hline Males . . . . . . . & $.64 \pm .027$ & 11 & 7 & 7 \\
\hline Females.... . & $.13 \pm .029$ & 14 & 5 & 10 \\
\hline Population .. & $.24 \pm .030$ & 17 & & \\
\hline
\end{tabular}

Note. Overlap $Z$ is $c / n ; c$ has been calculated for each possible pair of tagged individual plants as the ratio of the number of census dates in which both plants showed intense flowering ( $>50 \%$ of the flowers open) to the total number of census dates of intense flowering for that pair; and $n$ is the number of pairs. Overall no. of census dates refers to the blooming period. Synchrony is the maximum number of plants found during the blooming period of the population with intense flowering at the same time. $N=$ number of plants.

tions (A91 and B91) with an overall duration of up to 17 wk.

The overall length of the flowering period depends on the mean flowering length of individual plants, both for sex and population (males: $r=$ $0.99, P<.01$; females: $r=0.98, P<.1$; population: $r=0.97)$. This means that in Viscum cruciatum the flowering period is not produced by staggering blooming individuals. We found a positive correlation between the overall flowering length and the intense flowering length in males $(r=0.72)$; this correlation is negative in females $(r=-0.82)$. The intense flowering in males during the study period was proportional to the overall flowering length, whereas in females the longer the flowering span, the lower the intense flowering. Annual rainfall and temperature data, possible causes for these observed flowering differences, are not available for the study period. There

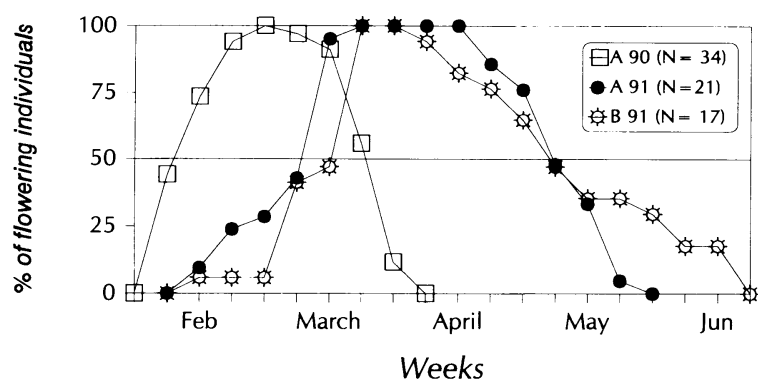

Fig. 2 Flowering dynamics in the studied populations and years. $N=$ number of individual plants.

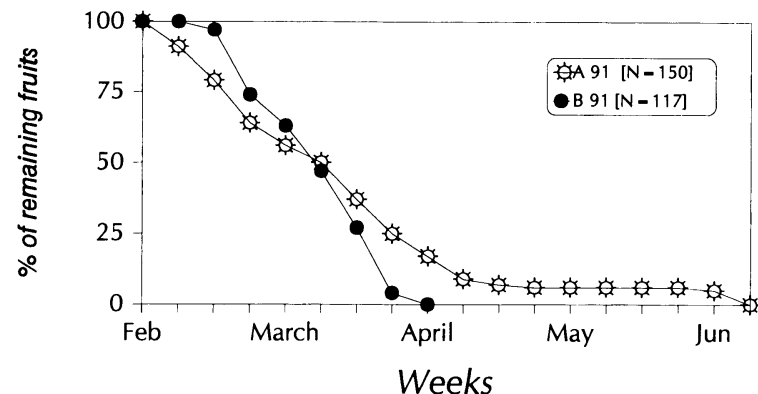

Fig. 3 Dynamics of fruit removal in the studied populations. $N=$ initial number of fruits.

is no correlation $(r=0.47)$ between overlap at the population level and final fruit set in control branches.

The fruit maturation span extends into the following year when the fruits turn red. We found that most fruits were consumed by birds by late March in B91, while in A91 fewer than 10\% lasted into the summer (fig. 3). We have confirmed the existence of this pattern for the same populations in recent years, so the differences may be caused by the birds living in these two very different ecosystems.

\section{FLORAL AND FRUIT CHARACTERISTICS}

Male flowers in $V$. cruciatum are lemon-scented but do not secrete nectar. They are usually composed of a four-part green perianth to which four polysporangiate anthers are fused on the inner side (fig. $4 a, b$ ). The mean dry mass was 14.4 $\pm 1.09 \mathrm{mg}(N=234)$, the mean length is $7.2 \pm$ $0.11 \mathrm{~mm}(N=200)$, and the mean number of pollen grains is $58,458 \pm 4,991$. Thus, the RSE is 4,059. Female flowers (fig. 4c) are odorless, green, and ovoid with four dull yellowish, rarely fully opening tepals inserted above the middle. The mean dry mass was $2.76 \pm 0.2 \mathrm{mg}(N=$ $789)$, of which $2.01 \pm 0.18(73 \%)$ corresponds to the ovary. The mean length of female flowers was $2.6 \pm 0.03 \mathrm{~mm}(N=789)$. There is neither a style nor a clear stigma in the ovary; this can be better distinguished as a rough brown surface in the ripe fruit within the perianth scars.

After 1 wk under laboratory conditions, nectar production in cut female flowers was $0.28 \pm 0.01$ $\mu \mathrm{L}$ per day with a mean sugar concentration of $19.58 \% \pm 1.01 \%$. Thus the daily amount of sugar secreted per flower was $0.05 \mathrm{mg}$.

The mean fresh mass of the fruit was $178 \pm 6$ $\mathrm{mg}$, and the number of embryos they contained varied from one to four (table 3). No correlation between mass (and size) and number of embryos $(r=0.017)$ was noted. Fruit diameter in population A was $6.9 \pm 0.05 \mathrm{~mm}(N=124)$, while in population $\mathrm{C}$ it was $5.4 \pm 0.05 \mathrm{~mm}(N=106)$, i.e., significantly smaller $(t=24.1, P<.001)$.

In the fruits containing more than one embryo, 

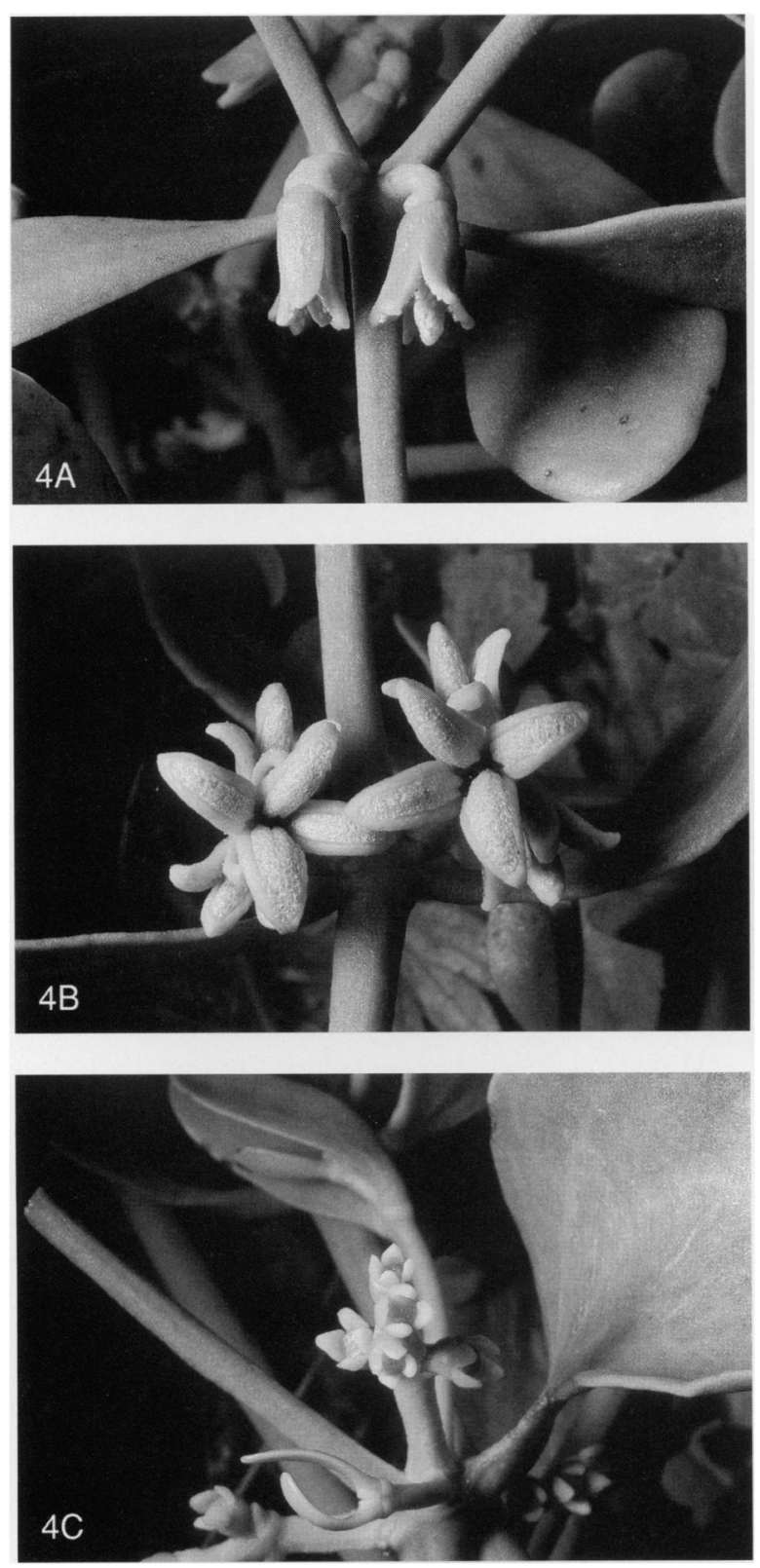

Fig. 4 Flowers of Viscum cruciatum. A, Lateral view of a male flower just starting to open. $B$, Underside side view of a male flower close to withering. Note the anthers fused to the tepals and that pollen has already been removed. $C$, Female flower.

we found a partly or completely fused endosperm that enclosed the embryos (fig. 5). This probably results from the development of two or more fertilized embryo sacs within the ovary.

\section{POLLINATION AND FRUIT SET}

The flowers were visited intensively by honeybees, although some other insects, especially Diptera, were sometimes captured. Each flower remained open for a period of 1-2 wk.
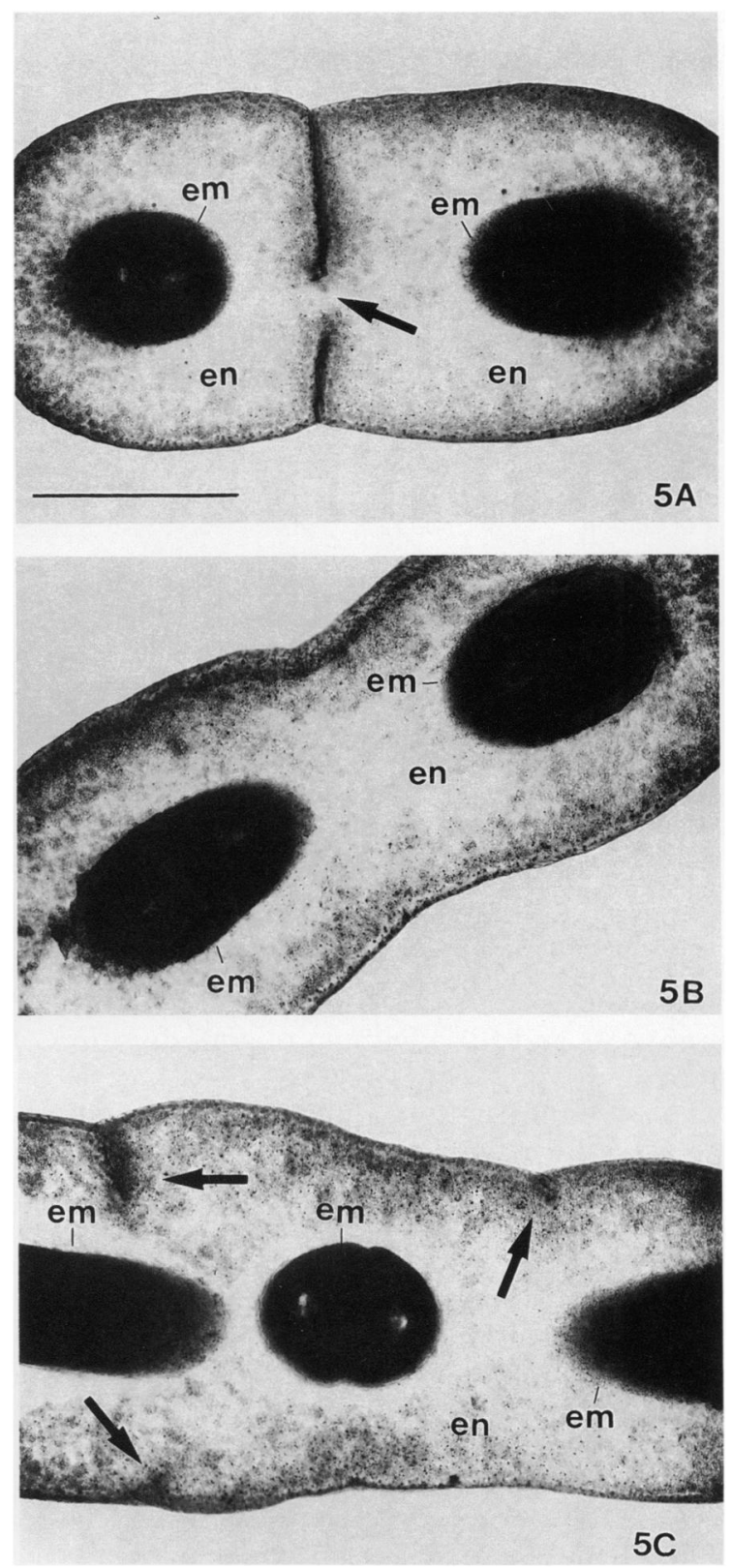

Fig. 5 Cross section of "seeds" (fresh pericarp have been removed) containing two and three embryos within a more or less common endosperm. $A, A$ "seed" with two embryos with partially fused endosperm (arrow). $B$, The same, but with totally fused endosperm. Only the curvature in the "seed" surface is noticeable. $C$, A "seed" with three embryos with short separations (arrows) indicating the compound nature of the endosperm. $e m=$ embryo; $e n=$ endosperm. Scale bar $=$ $1 \mathrm{~mm}$.

None of the 629 flowers bagged with dense cloth (excluding wind and insect pollination) set fruit (table 4). In contrast, the control branches produced an average of close to $50 \%$, and those tagged with nylon $7 \%$. Fruit production is therefore insect dependent $\left(t_{\mathrm{s}}=30.08, P<.0001\right)$ and the significant differences in fruit set between years 
Table 3

Percent AND WeIGHT OF FrUits ACCORdING TO THE NUMBER OF EMBryos

\begin{tabular}{|c|c|c|c|c|}
\hline & \multicolumn{4}{|c|}{ No. of embryos } \\
\hline & 1 & 2 & 3 & 4 \\
\hline Percent of total ${ }^{a}$ & 45 & 43.6 & 11 & .3 \\
\hline Mean mass $(\mathrm{g})^{\mathrm{b}}$ & $.17 \pm .01$ & $.18 \pm .009$ & $.17 \pm .01$ & $\ldots$ \\
\hline
\end{tabular}

a $N=353$.

b $N=100$.

and populations (table 5) indicate the existence of ecological factors that influence the final fruit set. Nevertheless, we have noticed that because the maturation of fruit takes a rather long time, many of the developing ovaries may be lost before the final fruit set (table 4). The final rate results therefore not only from the reproductive success of pollination or fertilization but also from ecological factors such as summer drought or predation.

\section{Discussion}

Both male and female plants of Viscum cruciatum are physiologically active year-round without any resting period, and the hemiparasitic habit may have played the main role in maintaining this physiological activity throughout the year, as the uptake of water and metabolites is possible even under unfavorable conditions. The same seems to have occurred in other Mediterranean hemiparasitic species within the Santalales, such as Osyris quadripartita, from southern Spain (Herrera 1984).

In the study area, flowering and fruit set of $V$. cruciatum occurred in winter and early spring. The flowering is separated from the fruiting season of the next year, when the fruits are available to dispersers, mainly Sylvia atricapilla (C. M. Herrera 1986), by only a few weeks. This early flowering may therefore increase the competition for the scarce pollinators (Petanidou and Vokou 1993) but allow enough time for ripening of the nutritive fruits (Herrera 1981). From the data in Fyfe (1969) and Fronchot and Salle (1980), the

Table 4

Percent of Fruit Set in the three tagGed BRANCHES IN EACH POPULATION

\begin{tabular}{lccc}
\hline & Cloth & Nylon & $\begin{array}{c}\text { Control } \\
\text { (Maximum) }\end{array}$ \\
\hline A90 $\ldots \ldots \ldots$ & 0 & 11 & $65.7(\cdots)$ \\
A91 $\ldots \ldots \ldots$ & $\ldots$ & .3 & $31.5(64.5)$ \\
B91 $\ldots \ldots \ldots$ & 0 & 10.9 & $56.7(75.4)$ \\
Average $\ldots .$. & 0 & 7.05 & $51.48(\cdots)$
\end{tabular}

Note. The maximum corresponds to the highest percentage of fertilized ovaries recorded during the ripening season. related $V$. album from western Europe has a phenology pattern similar to that of $V$. cruciatum. However, in dry areas of South Africa, V.combreticola shows uninterrupted flowering and fruiting seasons (Godschalk 1983a), as in other Santalaceae of the Mediterranean shrublands in South Africa (Le Roux et al. 1989) and Osyris quadripartita of southern Spain (Herrera 1984).

The flowers show insect-pollination features and are not as small $(<3 \mathrm{~mm})$ as reported for Loranthaceae and Viscaceae (Barlow 1964, 1983; Calder 1983). The male flowers in V. cruciatum (Danser 1941; Ruíz de Clavijo 1987) seem to be exceptionally large. Although not showy, male flowers are fragrant but only females produce nectar. The daily amount of sugar in relation to the dry mass of the female flower is the lowest of the shrubs of the Mediterranean southern Spain (Herrera 1985). The nectar volume is also quite low. This scarce nectar reward becomes meaningful considering that thousands of female and male flowers are open at the same time within the dense and relatively small populations of $V$. cruciatum. The yield of pollen grains per milligram of male flower dry mass (RSE is low and, therefore, indicates an insect-pollination system.

The results of the bagging experiments confirm that insects are absolutely necessary for the highest fruit set in $V$. cruciatum. Our results do not support the views of Hatton (1966), who reported greater efficiency of wind than insect pollination for the closely related $V$. album. Nevertheless, male flowers are usually nodding at anthesis (fig. $4 a$ ), and the sticky and spiny pollen (A. Aparicio, personal observation; Fernández 1987) can, to some extent, be transported to the nearest female

Table 5

VALUES OF $t_{\mathrm{s}}$ FOR FRUIT SET BETWEEN POPULATIONS AND POLLINATION EXPERIMENTS

\begin{tabular}{llcc}
\hline & & Nylon & Control \\
\hline A90-A91 $\ldots \ldots \ldots$ & $8.6^{* * *}$ & $11.3^{* * *}$ \\
A90-B91 $\ldots \ldots \ldots$ & $.52^{\text {a }}$ & $3.0^{* *}$ \\
A91-B91 $\ldots \ldots \ldots$ & $9.3^{* * *}$ & $7.6^{* * *}$ \\
\hline
\end{tabular}

a Not significant.

** $P<.002$.

*** $P<.0001$. 
flowers by wind. Our observations, in fact, tend to show that the isolated female plants did not produce any fruit in nylon-bagged branches, whereas those with a male individual nearby set some fruits. Branches visited by insects (controls) set significantly more fruit, but that does not eliminate the possibility that some fruit set results from incidental wind pollination.

Most of the dioecious species of mistletoes show the predominant female-biased sex ratio, although there is documentation for unity or malebiased ratios (Barlow and Wiens 1976; Barlow et al. 1978; Wiens and Barlow 1979; Dawson et al. 1990). In V.cruciatum all the populations studied (Barlow et al. 1978; Aparicio 1993) show a strong female bias ranging from 0.2 to 0.5 . In the studied species of mistletoes, the chromosomal rearrangements involved in the control of sex determination have been interpreted as causing the sex-ratio distortion through some kind of gamete selection (Barlow and Wiens 1976). Nevertheless, not all species with permanent translocation heterozygosity showed biased sex ratios. Therefore some other causes, possibly ecological and increasing female fitness, should be considered (Wiens and Barlow 1979). Barlow et al. (1978) and Aparicio (1993) speculated that agamospermous seed production in Viscum could be related to female bias. The results of our study do not support this view because no single flower bagged against wind or insect pollination set fruit. Agamospermy therefore does not occur in $V$. cruciatum. The fruit, a "pseudoberry enclosing a single naked seed" (Bhandari and Vohra 1983), bears more than one embryo within such "seeds" (Fronchot and Sallé 1980; Godschalk 1983b; Sallé 1983). Barlow and Wiens (1976, p. 30) refer to this as "occasional polyembryony in some viscaceous mistletoes." We have found that more than half of the fruits bore more than one embryo, up to four in some fruit. But the existence of a massive sporogenous tissue in the ovary base of some Viscum species (Barlow and Wiens 1976; Barlow 1981) and in V. cruciatum (in which up to 10 megaspore mother cells complete meiosis; A. Aparicio, personal observation) leads us to believe in the existence of as many seeds as embryos within the berry with a fused endosperm.
This is consistent with the view that ovules are reduced to megasporangia (Richardson 1978). The anatomy of these "seeds" also points to the collective nature of the chlorophyllous endosperm, as in most of the related Loranthaceae that show this peculiar embryological feature (Bhatnagar and Johri 1983). True polyembryony does not exist and is not the cause of the sex-ratio distortion in $V$. cruciatum. According to our study, the number of embryos within a fruit must be related to the reproductive features: number of developed embryo sacs, pollination, fertilization, and the mass of the fruits, with the ecological variables such as age and health of the female plants and altitude or host plant.

Weak correlations have been encountered between variations in flowering time and plant attributes such as number of fruits produced or number of seeds per fruit, in some years and populations of some plant species (Primack 1980). In this study we have not detected that the flowering phenology on the basis of overlap and synchrony is responsible for the final amount of fruit set. Many other ecological factors are involved either during the flowering or, as we have noted, during the long ripening period, especially the critical summertime stress. We do not know whether rainfall and/or temperature are direct causes for the general diminishing of the fruit during 1991 and the differences in flowering of only the females. Nevertheless, the extent of genetically mediated abortion-not resource limited-of embryos affecting the preemergent success (Wiens 1984; Wiens et al. 1987, 1989) remains to be investigated.

\section{Acknowledgments}

We thank Dr. S. Silvestre for commentaries and encouragement and Dr. J. Herrera for reading and commenting on the manuscript. We acknowledge the valuable commentaries and criticisms of Dr. P. Bernhardt and an anonymous reviewer. We are also indebted to J. C. Neva (authority of the Parque Natural de la Sierra de Grazalema) for permission to work in the preserved area and to D. M. Ferreras (Cordoba University) for identifying the bees.

\section{Literature cited}

Aparicio A 1991 Translocaciones recíprocas y dioecia en Viscum cruciatum Sieber en el S de España. Candollea 46: 95-99.

1993 Sex-determining and floating translocation complexes in Viscum cruciatum Sieber ex Boiss. (Viscaceae) in southern Spain: some evolutionary and ecological comments. Bot J Linn Soc 111:359-369.

Aparicio A, S Silvestre 1987 Flora del Parque Natural de la Sierra de Grazalema. Agencia de Medio Ambiente (Junta de Andalucía), Sevilla.

Ayuso MJ, C De Miguel, MT Sáenz 1985 Activité cytos- tatique de Viscum cruciatum Sieber sur des cultures cellulaires. Toxicité aiguë. Ann Pharm Fr 43:459-461.

1987 Influence of the host plant in the cytostatic activity of Viscum cruciatum Sieber. Phytotherapy Res 1:9394.

Barlow BA 1964 Classification of the Loranthaceae and Viscaceae. Proc Linn Soc N S W 89:268-272.

1981 Viscum album in Japan: chromosomal translocations, maintenance of heterozygosity and the evolution of dioecy. Bot Mag Tokyo 94:21-34.

1983 Biogeography of Loranthaceae and Viscaceae. 
Pages 19-45 in M Calder, P Bernhardt, eds. The biology of mistletoes. Academic Press, Sydney.

Barlow BA, D Wiens 1975 Permanent translocation heterozygosity in Viscum hildebrandtii Engl. and $V$. englerii Tiegh. (Viscaceae). Chromosoma 53:265-272.

1976 Translocation heterozygosity and sex ratio in Viscum fischeri. Heredity 37:27-40.

Barlow BA, D Wiens, C Wiens, WH Busby, C Brighton 1978 Permanent translocation heterozygosity in Viscum album and $V$. cruciatum: sex association, balanced lethals, sex ratios. Heredity 40:33-38.

Bhandari NN, CA Vohra 1983 Embryology and affinities of Viscaceae. Pages 69-85 in M Calder, P Bernhardt, eds. The biology of mistletoes. Academic Press, Sydney.

Bhatnagar SP, BM Johri 1983 Embryology of Loranthaceae. Pages 47-66 in M Calder, P Bernhardt, eds. The biology of mistletoes. Academic Press, Sydney.

Calder DM 1983 Mistletoe in focus: an introduction. Pages 1-17 in M Calder, P Bernhardt, eds. The biology of mistletoes. Academic Press, Sydney.

Danser B 1941 The British-Indian species of Viscum revised and compared with those of South-Eastern Asia, Malaysia and Australia. Blumea 4:261-319.

Dawson TE, JR Ehleringer, JD Marshall 1990 Sex-ratio and reproductive variation in the mistletoe Phoradendron juniperinum (Viscaceae). Am J Bot 77:584-589.

Fernández I 1987 Viscaceae. Page 210 in B Valdés, MJ Díez, I Fernández, eds. Atlas polínico de Andalucía Occidental. Instituto de Desarrollo Regional de la Univeridad de Sevilla y Excelentísima Diputación de Cádiz, Sevilla.

Fronchot H, M Pitsch, L Wehrlen 1978 Differences de sensibilité au gui (Viscum album L.) de quelques clones de peuplier (Populus sp.). Proceedings of the $103^{\mathrm{e}}$ Congrés national des Sociétés savantes 1:371-380.

Fronchot H, G Sallé 1980 Modalités de dissémination et d'implantation du Gui. Rev For Fr 32:505-519.

Fyfe A 1969 The mistletoe in the cycle of the seasons. $\mathrm{Br}$ Homeopathical J 8:227-240

Gill LS, FG Hawksworth 1961 The mistletoes: a literature review. Tech Bull US Dep Agric For Serv 1242:1-87.

Godschalk SBK $1983 a$ The morphology of some South African mistletoe fruits. S Afr J Bot 2:52-56.

$1983 b$ Mistletoe dispersal by birds in South Africa. Pages 117-128 in M Calder, P Bernhardt, eds. The biology of mistletoes. Academic Press, Sydney.

$1983 c$ The reproductive phenology of three mistletoe species in the Loskop Nature Reserve, South Africa. S Afr J Bot 2:9-14.

-1985 Feeding behaviour of avian dispersers of mistletoe fruit in the Loskop Dam Nature Reserve, South Africa. S Afr J Zool 20:136-146.

Hariri B, G Sallé, C Andary 1990 Mécanismes de résistance de quatre cultivars de peuplier en résponse à l'attaque de gui (Viscum album L.). C R Acad Sci Paris Ser III 311:439444.

Hatton RHS 1966 Pollination of mistletoe ( $V$. album L.). Proc Linn Soc Lond 176:67-76.

Hawksworth FG 1961 Dwarfmistletoe of ponderosa pine in the Southwest. USDA Forest Service, Techical Bulletin no. 1246. USDA, Washington, D.C.

Hawksworth FG, DW Johnson 1989 Biology and management of dwarf mistletoe in lodgepole pine in the Rocky Mountains. USDA Forest Service, General Technical Report RM-169. USDA, Washington, D.C.

Hawksworth FG, D Wiens 1972 Biology and classification of dwarf mistletoe (Arceutobium). USDA Forest Service, Agriculture Handbook no. 401. USDA, Washington, D.C.

Herrera CM 1981 Are tropical fruits more rewarding to dispersers than temperate ones? Am Nat 118:896-907.
1984 The annual cycle of Osyris quadripartita, a hemiparasitic dioecious shrub of Mediterranean scrublands. J Ecol 72:1065-1078.

1986 Vertebrate-dispersed plants: why they don't behave the way they should. Pages 5-18 in A Estrada, TH Fleming, eds. Frugivores and seed dispersal. Junk, Dordrecht.

Herrera J 1985 Nectar secretion patterns in southern Spanish Mediterranean shrublands. Isr J Bot 34:47-58.

1986 Flowering and fruiting phenology in the coastal shrublands of Doñana, south Spain. Vegetatio 68:91-98.

1987 Flower and fruit biology in southern Spanish Mediterranean shrublands. Ann Mo Bot Gard 74:69-78.

Le Roux A, P Perry, X Kyriacou 1989 South Africa. Pages 159-345 in G Orshan, ed. Plant pheno-morphological studies in Mediterranean type ecosystems. Kluwer, Dordrecht.

Mechelke F 1976 Sex-correlated complex heterozygosity in Viscum album L. Naturwissenschaften 8:390.

Meyer von Freyhold O 1987 Southern Spain: reversion of Viscum album L. to Viscum cruciatum Sieb. (Viscaceae). Pages 547-562 in HC Weber, W Forsttreuter, eds. Parasitic flowering plants. Proceedings of the 4th International Symposium on Parasitic Flowering Plants, Philipps University, Marburg.

Petanidou T, D Vokou 1993 Pollination ecology of Labiatae in a phryganic (East Mediterranean) ecosystem. Am J Bot 80:892-899.

Primack RB 1980 Variation in phenology of natural populations of montane shrubs in New Zealand. J Ecol 68:849862.

Richardson IBK 1978 Loranthaceae. Pages 174-175 in VH Heywood, ed. Flowering plants of the world. Oxford University Press, Oxford.

Ruíz de Clavijo E 1987 Viscaceae. Pages 214-215 in B Valdés, S Talavera, EF Galiano, eds. Flora Vascular de Andaucía Occidental. Ketres Editores, Barcelona.

Sallé G $1979 a$ Relations cyto-physiologiques entre le Viscum album L. et le Pommier. Bull Soc Bot Fr Actual Bot 4:79-95.

— $1979 b$ The endophytic system of Viscum album: its anatomy, ultrastructure and relations with the host tissues. Pages 115-127 in Proceedings of the Second Symposium of Parasitic Weeds. North Carolina State University, Raleigh.

1983 Germination and establishment of Viscum album L. Pages 145-159 in M Calder, P Bernhardt, eds. The biology of mistletoes. Academic Press, Sydney.

Wiens D 1984 Ovule survivorship, brood size, life history, breeding systems, and reproductive success in plants. Oecologia 64:47-53.

Wiens D, B Barlow 1973 Unusual translocation heterozygosity in East African mistletoe (Viscum fisherii). Nature 243:93-94.

1975 Permanent translocation heterozygosity and sex determination in East African Mistletoes. Science 187: 1208-1209.

1979 Translocation heterozygosity and the origin of dioecy in Viscum. Heredity 42:201-222.

Wiens D, CL Calvin, CA Wilson, CI Davern, D Frank, SR Seavey 1987 Reproductive success, spontaneous embryo abortion, and genetic load in flowering plants. Oecologia 71:501-509.

Wiens D, DL Nickrent, CI Davern, CL Calvin, NJ Vivrette 1989 Development failure and loss of reproductive capacity in the rare paleoendemic shrub Dedeckera eurekensis. Nature 338:65-67. 